\title{
Almát a körtével? Tudománymetriai összehasonlítások szakterületek között
}

\author{
Schubert András \\ MTA Könyvtár és Információs Központ, Tudománypolitikai és Tudományelemzési Osztály, Budapest
}

\begin{abstract}
Közismert tény, hogy a tudománymetriai mutatószámok mindegyike erősen függ a szakterülettől. Sokan ezért eleve idegenkednek e mutatószámok szakterületek közötti bármiféle összehasonlításától. A szerző áttekinti azokat a lehetőségeket, amelyek a legfontosabb tudománymetriai mutatószámok: a publikációszám, az idézettség vagy a h-index normalizálására és ezen keresztül a szakterületek közötti összehasonlítására felhasználhatók. Orv. Hetil., 2016, 157(16), 631-634.
\end{abstract}

Kulcsszavak: tudománymetria, mutatószámok, szakterületek közötti összehasonlítás

\section{Apples with oranges? Comparison of scientometric indicators between fields}

\begin{abstract}
It is well known that all scientometric indicators strongly depend on research fields. Therefore, there is a certain reluctance to make any cross-field comparison of these indicators. The paper reviews the possibilities to normalize the most important scientometric indicators: publication counts, citation rate or h-index, thus making them suitable for cross-field comparison.
\end{abstract}

Keywords: scientometrics, indicators, cross-field comparison

Schubert, A. [Apples with oranges? Comparison of scientometric indicators between fields]. Orv. Hetil., 2016, $157(16), 631-634$.

(Beérkezett: 2016. február 7.; elfogadva: 2016. február 25.)

„Az összehasonlítások utálatosak” - tartja az évszázados bölcsesség [1]. Az évszázados patina azonban nem feltétlenül jelent megfellebbezhetetlen igazságot. Egy másik - számomra régóta irányadó és emlékeim szerint (más forrásra nem akadtam) Samuel Johnsontól származó mondás szerint „minden hasonlat félrevezető, de semmi sem kevésbé félrevezető, mint egy jó hasonlat”. Ami pedig a címben szereplő párosítást illeti, én személy szerint ki nem állhatom a körtét, tehát számomra az összehasonlítás triviális: a legrosszabb alma is jobb, mint a legjobb körte.

A lényeg talán az, hogy nem a dolgokat magukat kell összehasonlítani, hanem meghatározott minőségi vagy mennyiségi tulajdonságaikat. Aligha vitatja bárki, hogy össze lehet hasonlítani egy alma és egy körte színét vagy súlyát. A következő kérdés az összehasonlítás relevanciája. Milyen következtetést vonhatunk le az összehasonlítás eredményéből?
Ezeket a szempontokat kell szem elött tartani a tudománymetriai összehasonlítások esetében is. Meg kell találni a mérhető és összemérhető tulajdonságokat, és gondosan meg kell fontolni az összehasonlítás eredményéből levonható következtetéseket.

A mutatószámok szakterületek közötti összehasonlításának módszere általában az, hogy a mutatószámokat a saját szakterületükre vonatkozó sztenderdekhez kell mérni, és az így normalizált mutatószámokat lehet azután összemérni.

\section{Publikációs termelékenység}

A publikációs termelékenység szakterületek közötti öszszehasonlításának a legfóbb akadálya az, hogy - bármilyen meglepő - a legkevésbé erre a mutatószámra állnak rendelkezésre megbízható szakterületi sztenderdek. Ennek oka fóképpen az, hogy a nagy bibliográfiai adatbázi- 
sokban a legutóbbi időkig a szerzőket csak a családnév és egy-két névbetú jelölte, és ennek alapján a személyeket nem lehetett egyértelmúen azonosítani. A publikációs produktivitási listák élén általában a Wang, $\Upsilon$., Li, J., Tanaka, K. vagy Smith, J. nevek szerepeltek, esetenként több ezer publikációval.

A problémát csak részben orvosolták azok a próbálkozások, amelyek a neveket automatikus, szövegelemzési módszerekkel igyekeztek azonosítani. Igen kifinomult módszereket alkottak, amelyeket több-kevesebb sikerrel próbáltak ki az orvosi szakirodalom nagy adatbázisain is $[2,3]$. Konkrét eredmények azonban legfeljebb egy-két szúk szakterületen, illetve néhány kisebb országra vonatkozóan születtek.

Gyökeres változást hozhatnak azok a szerzői azonosítók (Researcher ID, ORCID, Scopus Author ID), amelyek a legutóbbi években kezdenek meghonosodni a bibliográfiai adatbázisokban. Ha ezek valóban beépülnek a nagy nemzetközi és multidiszciplináris adatbázisokba (Web of Science, Scopus), akkor reménykedhetünk széles körú, nagy adatmennyiségre alapozott elemzések elkészültében, amelyek alapul szolgálhatnak a szerzői produktivitás szakterületek közötti összehasonlításához is.

\section{Idézettség}

Az idézetelemzés kezdetei óta nyilvánvaló, hogy a tudományos cikkre kapott idézetek száma rendkívül erősen függ a szakterülettől. Ezt alapvető szempontként kell figyelembe venni a kutatói teljesítmény idézettség alapján történő megítélése során is. Garfield már évtizedes tapasztalatként szúri le könyvében [4] a tanulságot: „Ahelyett, hogy közvetlenül hasonlítanánk össze egy matematikust mondjuk egy biokémikussal, először mind a kettőt saját kollégáik között kell rangsorolnunk, és utána a saját rangsorukban elfoglalt helyezésüket hasonlíthatjuk öszsze."

Általánosan véve cikkeket hasonló cikkekkel, kutatókat hasonló kutatókkal, intézményeket hasonló intézményekkel, folyóiratokat hasonló folyóiratokkal kell összehasonlítani. A „hasonlóság” pontos meghatározása, illetve a hasonló elemek kiválasztása az a kérdés, amelyre a tudománymetriai kutatások évtizedek óta keresik a legjobb választ.

A legkézenfekvőbb megközelítés a létező szakterületi besorolásokból indul ki. A nagy bibliográfiai adatbázisok (Web of Science, Scopus, MEDLINE/PubMed) mind

1. táblázat |A különböző korú publikációk átlagos idézettsége az egyes szakterületeken (A Thomson-Reuters Essential Science Indicators 2016. januári adatai alapján)

\begin{tabular}{|c|c|c|c|c|c|c|c|c|c|c|c|}
\hline \multirow[t]{2}{*}{ Szakterület } & \multicolumn{11}{|c|}{ A publikálás óta eltelt évek száma } \\
\hline & 0 & 1 & 2 & 3 & 4 & 5 & 6 & 7 & 8 & 9 & 10 \\
\hline Anyagtudományok & 0,49 & 2,80 & 5,56 & 8,35 & 10,63 & 12,85 & 13,96 & 14,99 & 16,71 & 16,13 & 17,07 \\
\hline Biológia és biokémia & 0,48 & 2,89 & 6,57 & 10,45 & 14,24 & 18,19 & 22,15 & 24,88 & 27,86 & 31,14 & 34,15 \\
\hline Farmakológia és toxikológia & 0,37 & 2,31 & 5,23 & 8,17 & 10,87 & 14,13 & 16,73 & 19,62 & 22,03 & 24,81 & 25,82 \\
\hline Fizika & 0,50 & 2,58 & 5,19 & 7,98 & 9,91 & 12,28 & 14,12 & 15,62 & 16,19 & 17,24 & 18,68 \\
\hline Földtudományok & 0,42 & 2,04 & 4,71 & 7,53 & 10,59 & 12,91 & 15,84 & 17,60 & 19,16 & 22,13 & 23,58 \\
\hline Ideg- és viselkedéstudományok & 0,50 & 2,98 & 6,85 & 11,10 & 15,40 & 19,83 & 23,86 & 27,10 & 31,50 & 34,01 & 37,82 \\
\hline Immunológia & 0,56 & 3,41 & 7,76 & 12,01 & 16,84 & 21,41 & 26,09 & 29,74 & 33,56 & 36,71 & 40,79 \\
\hline Kémia & 0,61 & 3,36 & 6,73 & 10,25 & 12,81 & 15,37 & 17,14 & 19,26 & 20,04 & 21,86 & 23,61 \\
\hline Klinikai orvostudomány & 0,40 & 2,23 & 5,13 & 8,16 & 11,07 & 14,07 & 16,93 & 19,22 & 21,88 & 25,15 & 27,84 \\
\hline $\begin{array}{l}\text { Környezettudományok, } \\
\text { ökológia }\end{array}$ & 0,39 & 2,08 & 4,93 & 8,21 & 11,16 & 14,56 & 17,11 & 20,71 & 23,41 & 26,09 & 29,28 \\
\hline Közgazdaság-tudomány & 0,19 & 0,87 & 2,22 & 3,82 & 5,89 & 7,97 & 9,92 & 11,60 & 14,42 & 17,38 & 19,53 \\
\hline Matematika & 0,13 & 0,65 & 1,49 & 2,50 & 3,59 & 4,72 & 5,57 & 6,42 & 7,08 & 7,80 & 8,44 \\
\hline Mezőgazdaság-tudomány & 0,27 & 1,43 & 3,26 & 5,12 & 6,94 & 8,95 & 10,52 & 12,08 & 14,58 & 16,66 & 18,11 \\
\hline Mikrobiológia & 0,43 & 2,80 & 6,22 & 9,37 & 12,94 & 17,70 & 20,89 & 23,34 & 26,87 & 30,04 & 33,98 \\
\hline $\begin{array}{l}\text { Molekuláris biológia } \\
\text { és genetika }\end{array}$ & 0,60 & 3,99 & 9,55 & 15,24 & 22,03 & 28,13 & 34,08 & 39,05 & 46,02 & 49,58 & 54,07 \\
\hline Mûszaki tudományok & 0,24 & 1,41 & 3,11 & 4,71 & 6,46 & 7,95 & 9,19 & 9,57 & 10,77 & 11,15 & 11,13 \\
\hline Növény- és állattan & 0,29 & 1,52 & 3,46 & 5,44 & 7,59 & 9,82 & 11,63 & 13,09 & 14,93 & 17,22 & 18,57 \\
\hline Pszichiátria és pszichológia & 0,33 & 1,76 & 4,12 & 6,88 & 10,11 & 13,39 & 16,11 & 19,56 & 23,08 & 25,77 & 28,88 \\
\hline Számítástudomány & 0,18 & 1,06 & 2,48 & 3,96 & 5,73 & 7,29 & 8,90 & 9,51 & 10,55 & 7,45 & 7,86 \\
\hline Társadalomtudományok & 0,23 & 0,94 & 2,24 & 3,68 & 5,30 & 7,06 & 8,51 & 10,06 & 12,40 & 14,26 & 15,71 \\
\hline Ürtudományok & 0,86 & 4,48 & 8,64 & 12,55 & 16,29 & 19,93 & 22,69 & 23,24 & 26,85 & 29,37 & 29,71 \\
\hline
\end{tabular}


tartalmaznak szakterületi kategóriákat, és ezek alapján meg lehet határozni különféle publikációs és idézettségi időtartamokra vonatkozó idézettségi sztenderdeket. Az adatbázisok kiegészítő szolgáltatásai készen kínálnak ilyen táblázatokat. Példaképpen az 1 . táblázat egy ilyen összeállítást mutat be a Web of Science-hez kapcsolódó Essential Science Indicators (ESI) nyomán.

A szakterületi besorolásokon alapuló idézettségi normalizálás legfőbb gyengesége a besorolások esetlegessége. Az ESI esetében első látásra feltűnő a szakterületek méret és specificitás szerinti heterogenitása. A fizika és az immunológia nyilvánvalóan nincs egy „súlycsoportban”, ugyanígy a klinikai orvostudomány és a mikrobiológia sem. Hasonló problémákkal terhelt a többi hasonló szakterületi kategóriarendszer is, ráadásul a különböző adatbázisok rendszerei nem kompatibilisek.

Majd' negyedszázaddal ezelőtti cikkünkben [5] három módszert javasoltunk az összehasonlítási alapul szolgáló sztenderdek kiválasztására.

1. Az egyes cikkek ténylegesen kapott idézettségét hasonlíthatjuk az ugyanabban a folyóiratban, ugyanabban az évben megjelent többi cikk idézettségéhez (a várható idézettséghez). A kettő aránya, a relatív idézettség megadja, hogy egy cikk vagy egy cikkhalmaz (például egy szerző vagy egy intézmény közleményei) mennyivel idézettebb vagy kevésbé idézett a közlő folyóiratok átlagánál.

2. Abban az esetben, ha a vizsgált közlemények nem a szakterület specifikus szakfolyóirataiban, hanem általánosabb, multidiszciplináris folyóiratokban jelentek meg, pontosabb eredményt adhat, ha a cikkek irodalomjegyzékében szereplő folyóiratok képezik az összehasonlítás alapját. Egy Nature-ben megjelent geológiai cikk irodalomjegyzékében feltehetően számos geológiai folyóirat található; ezek alapján valószínúleg reálisabb képet kapunk a cikk várható idézettségére, mint ha a Nature összes cikke alapján számolunk. Ugyancsak az irodalomjegyzékekben szereplő folyóiratok alapján tudjuk megítélni a folyóiratok relatív idézettségét.

3. A legmunkaigényesebb, de legtestreszabottabb öszszehasonlítási alap a vizsgált cikkhez bibliográfiailag csatolt cikkek halmaza. A bibliográfiai csatolás [6] azt jelen-
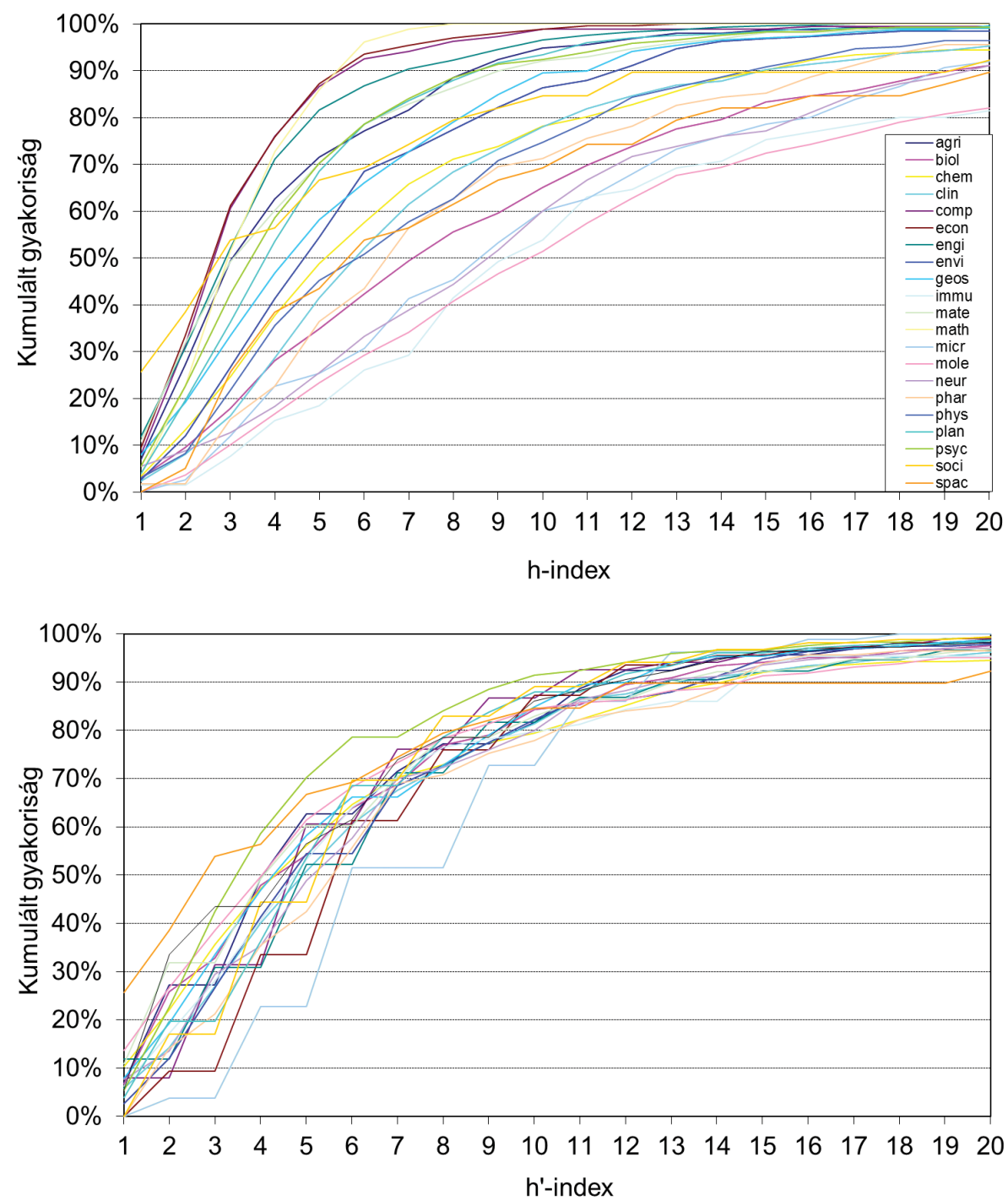

l. ábra | A folyóiratok normalizálatlan (h) és a normalizált (h') h-indexének eloszlása az ESI szakterületi besorolása szerint [12] 
ti, hogy azokat a cikkeket válogatjuk ki, amelyeknek az irodalomjegyzéke a legjobban hasonlít a vizsgált cikkéhez. A hasonló irodalomjegyzék jó eséllyel szoros tematikai hasonlóságot tükröz. Ez az eljárás megfelel a legújabban nagy népszerüségnek örvendő cikkszintű értékelés ( „article-level metrics”, „altmetrics”) alapkritériumának.

Lényegében mindmáig ezekre a módszertani elvekre épülnek az idézettség szakterületek közötti összehasonlítási módszerei. A cikkünket idéző száznál több publikáció között van a téma legidézettebb [7] és e munka írásáig legfrissebb [8] cikke egyaránt.

\section{$\mathrm{H}$-index}

Egy publikációhalmaz h-indexe függ a publikációk számától és idézettségétől is. A h-index szakterületi normalizálását tehát mindkét összetevő figyelembevételével lehet csak elvégezni. Glänzel [9] teremtette meg az elméleti alapjait annak a közelítésnek, amelynek első sikeres alkalmazását Csajbók és mtsai cikkében [10] találhatjuk. E szerint a h-index (h), a mintanagyság (n, a cikkek száma) és az átlagos idézettség (x) között a $\mathrm{h}=\mathrm{c} \mathrm{n}^{1 / 3} \mathrm{x}^{2 / 3}$; összefüggés áll fenn, ahol c 1 nagyságrendû pozitív állandó.

Ennek az összefüggésnek az alapján a h-indexet normalizálni lehet az egyes szakterületek jellemző publikációszám- és idézettségadatainak ismeretében. A normalizált h' indexet a teljes sokaság átlagos idézettsége $\left(\mathrm{x}_{0}\right)$ és a szakterületi átlag $(\mathrm{x})$ ismeretében a $\mathrm{h}^{\prime}=\left(\mathrm{x}_{0} / \mathrm{x}\right)^{2 / 3}$ képlet segítségével számíthatjuk ki $[11,12]$.

Az 1. ábrán bemutatjuk a folyóiratok normalizálatlan (h) és a normalizált (h') h-indexének eloszlását az ESI szakterületi besorolása szerint. Feltûnő, hogy a normalizálás után az indexek eloszlása lényegesen közelebb kerül egymáshoz, mint előtte volt, alátámasztva a módszer eredményességét.

\section{Zárszó}

Kétségtelen, hogy a tudománymetriai mutatószámok mindegyike - a legegyszerúbb publikációszámtól kezdve a különféle idézettségi mutatószámokon keresztül a legkifinomultabb hálózati mérőszámokig - erôsen szakterületfüggő. Ez azonban nem jelenti azt, hogy nem lehet módot találni a szakterületek közötti összehasonlításra. A legelső kérdés természetesen mindig az kell, hogy legyen, hogy van-e célja, és ha igen, akkor mi a célja az összehasonlításnak. Csak a cél pontos ismeretében találhatjuk ugyanis meg a célnak legjobban megfelelő eszközt. A folyóiratok szakterületek közötti összehasonlítása például ugyan jó modell lehet egy módszertani kísérletben, de nehéz elképzelni olyan gyakorlati problé- mát, amikor különböző szakterületeken múködő folyóiratokat kellene egymással összemérni.

A tudománymetriai mutatószámok szakterületi normalizálásának és ezen keresztül a szakterületek közötti összehasonlítás lehetőségének nagy irodalma van, és a nagy bibliográfiai adatbázisok hatalmas adattömegeinek feldolgozása egyre bővíti a lehetőségeket. Ezzel azonban a választás nehézsége is egyre fokozódik. Szakértelem és körültekintés kell az adott feladat megoldására legalkalmasabb eszköz kiválasztásához és alkalmazásához.

Anyagi támogatás: A szerző köszöni az FP7-SSH-2013-2 \#613202 (IMPACT-EV) projekt támogatását.

A cikk végleges változatát a szerző elolvasta és jóváhagyta.

Érdekeltségek: A szerzőnek nincsenek érdekeltségei.

\section{Irodalom}

[1] Primary source of the phrase "comparisons are odious" is John Lydgate: Debate between the Horse, Goose, and Sheep, cca. 1440. „Odyous of olde been comparisonis, and of comparisonis engendyrd is haterede." http://www.phrases.org.uk/meanings/Comparisons-are-odious.html

[2] Torvik, V. I., Smalbeiser, N. R.: Author name disambiguation in MEDLINE. ACM Transactions on Knowledge Discovery from Data, 2009, 3(3), 1-29.

[3] Liu, W., Dogan, R. I., Kim, S., et al.: Author name disambiguation for PubMed. J. Assoc. Inform. Sci. Technol., 2014, 65(4), $765-781$.

[4] Garfield, E.: Citation indexing. Its theory and applications in science, technology, and humanities. Wiley, New York, 1979.

[5] Schubert, A., Braun, T.: Reference standards for citation based assessments. Scientometrics, 1993, 26(1), 21-35.

[6] Kessler, M. M.: Bibliographic coupling between scientific papers. American Document, 1963, 14(1), 10-25.

[7] Radicchi, F., Fortunato, S., Castellano, C.: Universality of citation distributions: Toward an objective measure of scientific impact. Proc. Natl. Acad. Sci. U.S.A., 2008, 105(45), 17268-17272.

[8] Colliander, C.: A novel approach to citation normalization: A similarity-based method for creating reference sets. J. Assoc. Inform. Sci. Technol., 2015, 66(3), 489-500.

[9] Glänzel, W.: On the h-index - A mathematical approach to a new measure of publication activity and citation impact. Scientometrics, 2006, 67(2), 315-321.

[10] Csajbók, E., Berbidi, A., Vasas, L., et al.: Hirsch-index for countries based on Essential Science Indicators data. Scientometrics, 2007, 73(1), 91-117.

[11] Iglesias, J. E., Pecharromán, C.: Scaling the h-index for different scientific ISI fields. Scientometrics, 2007, 73(3), 303-320.

[12] Schubert, A.: Rescaling the h-index. Scientometrics, 2015, 102(2), 1647-1653. 